\title{
TEACHERS' PERCEPTIONS TOWARDS THE IMPLEMENTATION OF GROUP WORKIN TEACHING \\ ENGLISH TO YOUNG LEARNERS
}

Dani Agus S. U.

\begin{abstract}
Group work becomes one of the effective and efficient teaching methods in education. Many teachers believe that group work gives many benefits to students. Young learners have different learning characteristics with adult learners. They need particular teaching treatments that are different from adult learners. That matter raises the question of whether group work can be applied to young learners. This research aimed at investigating the teachers' perception towards the implementation of group work in teaching English to young learners. The participants of this study were four native English teachers who had experiences in teaching English to young learners. A questionnaire and interview were used to collect data and the results were analysed qualitatively through a descriptive approach. The research found that the participants had positive perceptions towards the implementation of group work in teaching English to young learners.
\end{abstract}

Keywords: group work, teachers' perception, teaching English to young learners.

\section{Introduction}

In learning English, students are expected to achieve the goals of the learning process. Learning goals should have been set by the teachers when planning the lesson. However, there are still some English teachers who are not innovative in presenting instructional materials when they come into the classroom. They only come, teach, and give tasks without giving a memorable lesson to the students during the teaching-learning 
process. Therefore, there are still many students who fail in English examination because of their lack of understanding towards the materials given by the teachers. Due to those situations, the researcher believes that teaching strategies in teaching English have a big impact on students' English comprehension.

One of the common strategies used in language teaching is group work. Through group work, students will have the opportunity to work together with peers around them and they will try to solve problems together as a group. The benefits of working in a group are immense as it allows both high and low academic achievers to learn from each other, as well as listen and compare different perspectives, ideas, and thoughts.

Young learners are a group of learners who are totally different from adult learners in many aspects. The matter of group work implementation in teaching young learners has long been debated. Scott and Ytreberg (1990) stated that young learners like to play and work alone. They also state that children are reluctant to share, which is called as selfcentered. Sugino's study (1994) found some teachers worried that students may start speaking in Japanese (first language) during group work or pick up ungrammatical forms. It also becomes one of the difficulties or problems during group work. Those become considerations for teachers when they want to use group work in the class. In a real condition, some young learners' teachers state that they need extra power to make young learners work together in group work. Meanwhile, another study found that group work can be part of the productive part of classroom activity (Blatchford, Galton, Kutnick, Baines, 2005). Raja (2012) implied that students need to be introduced to the importance of communication through working in a group. Last but not least, Ahmed (2013) also found that group work is one of the fundamental aspects of SLA learners and teachers.

According to the above evidence, the researcher conducted a research study on the implementation of group work in teaching English to young learners. The researcher will conduct an investigation on the 
teachers' perceptions towards the implementation of group work in teaching English to young learners.

\section{Research Methods}

This research was designed as a descriptive-qualitative research study which would describe the data interpretation of the study through some explanations and elaborations. This study analysed the condition of the research target where this research was conducted in a class during the teaching-learning process. According to Mathers, Fox \& Hunn (2007) argued that qualitative research studies behaviors in natural settings or uses people's accounts as data. In addition, Arikunto (1995) explained that the data was the result of documenting a certain set of activities by a researcher through observing, interviewing, experimenting, and testing. Therefore, this research employed the questionnaire and interview to investigate the teachers' perceptions towards the implementation of group work in teaching English to young learners.

The participants were four native teachers of the English subject. Those native teachers taught at different grades of the same school, but all of them were from lower grades, which were the primary one, two, and three. They were chosen as the participants of this study with the consideration that they had experience more than two years in teaching English for lower primary students (grade 1, 2, and 3). Besides that, to keep the privacy of participants, the researchers mentioned them initially which was P1 stood for the first participant, P2 stood for the second participant, P3 stood for the third participant, and P4 stood for the fourth participant.

An instrument tool in research was a prior term that should be prepared and arranged properly before the researcher started the study. The instrument used was based on the purpose of the study or what wouldbe investigated. This study employeda closed-response questionnaire; the questionnaire that provided several optional answers for participants. Beside that, the researcher also conducted interview to enrich the data. 
Questionnaires were a very convenient way of collecting useful comparable data from a large number of individuals. However, questionnaires could only produce valid and meaningful results if the statementswere clear and precise and if they were asked consistently across all respondents (Mathers, Fox \& Hunn, 2007). The questionnaire that was adopted from Arifin (2014) would contain several statements from three categories; the teachers' knowledge about TEYL and group work, the implementation of group work, and teacher's attitude toward the implementation of group work. The first categories revealed how teachers' opinion about the basic knowledge of TEYL and group work. There were five statements in this category; they were statement number 1 to number 5.The second category was about the implementation of group work. It consisted of eight statements, which were statement 6 to 13 that would provide the teachers' perceptions about how the group works to be implemented in the class. The last category consisted of seven statements that describedabout the teachers' feeling or attitude towards the implementation of group work. While for the interview, the researcher employed a structural interview, which wasmore controlled form so it had been formulated to elicit participant responses. It provided five leading questions to enrich the data and also to add the information in this research so that the researcher obtained the clear information about the research.The interview had been conducted in January 2019 on different days based on the spare time of each teacher. The data was in a recorded file; however, the researcher transcribed the interview in written form so that it would be easier to be analyzed.

The first data was taken from questionnaires that had been completed by the English teachers. The data from the questionnaire was displayed in percentage form and then it was described through the words. The researcher adopted Sugiyono's (2008) formula in finding the percentage of the data. This following is the formula.

$$
\mathrm{P}=\frac{f}{n} \times 100
$$


$\mathrm{P}=$ Percentages

$\mathrm{f}=$ the frequency of each questionnaire answer

$\mathrm{n}=$ number of participants

The data from the interview was analyzed by using three stages from Ary, Jacobs, Sorensen, \& Razavieh (2010) which were (1) organizing and familiarizing, this stage suggests the researcher be familiar with the data that has been obtained by reading, listening, and watching frequently. By familiarizing the data, the researcher is able to transcribe the data with good organizing. Thus, it is easier for the researcher to process the data into the next stage.(2) Coding and reducing, this stage helps the researcher to categorize the data based on its categories. The researcher puts the data that has been transcribed into some categories and reduces the data that is not necessary for the study. The last is (3) interpreting and representing, this stage the researcher brings out their understanding toward the data into report form. Even though there are no rules in interpreting qualitative research, it does not mean the data interpreted dragon the researcher's personal feeling when interpreting the data but it is also supported by the existing data.

\section{Finding and Discussion}

\section{Findings}

\section{The Result of the Questionnaire}

Based on the questionnaire there were three categories that were discussed in this study; teacher's knowledge about TEYL and group work, the implementation of group work, and teacher's attitude toward the implementation of group work. The first categoriesfound that most teachers agreed with statement 1 to 5 which meant that the participants have experienced and taught Young Learners using group work technique. While only a few of them did not quite understand about TEYL and group 
work. It indicated from statement 2 and 3 which were only a number of the teachers viewed that physical activities, authentic materials, and grouping as a team were not necessary when using group work in teaching English to young learners.

The second category was about the implementation of group work. Based on eights statements of this category indicated that the way teachers implemented group works had been done accordingly as what the second category was stated. It could be seen from the percentages of the teachers who agreed with eight statements of the second categories. Overall, it implied that most teachers showed positive perceptions about the implementation of group work.

The last category of the questionnaire presented the teachers' attitude towards the implementation of group work. There were seven statements that would give the percentage of teachers' perception of this term. The result stated that most of the participantsrevealed thepositive response toward the implementation of group work in teaching English to young learners. It could be seen from the participants' feedback in which they agreed with the statement. Although some teachers did not implement group work in their class, yet their perception toward group work was still positive. Most teachers consider that group work had numerous benefits and was a good strategy in TEYL.

\section{The Result of the Interview}

The interview had been conducted in January 2019 during school hour. The following were the results of the interview with four native English teachers.

P1 emphasized that group work was a good method to be implemented in teaching English to young learners. The evidence on the field about young learners focus became the main barrier for young learner teachers in applying group work. Therefore, teachers' control was necessary to carry out the group work accordingly. Moreover, he 
recommended that group work was acceptable to be implemented in teaching English to young learners.

P2 gave quite brief information about his thought toward the questions. However, he was supportive to the implementation of group work for the young learner. The barriers he encountered were still able to be maintained by him. The last he also recommended the implementation of group work for teaching English to young learners.

The similar thoughts also came from P3, he agreed that group work was a good method to apply in the class. Nonetheless, he did not recommend it for young learners who were at grade1 or 2 because they tended to have a conversation which would distract their focus. According to him, group work was better for higher level students.

Last but not least, P4 brought a positive attitude towards the implementation of group work in teaching English to young learner. Based on his experience, he assumed that young learner was even better when they were learning from their friends. It was because of young learners would pay more attention when they were working with their peers.

\section{Discussion}

This section presented the discussion based on the finding of the study. There were two discussion would be elaborated which were about the finding of the questionnaires and the interviews.

The first category in the questionnaire was about teachers' knowledge about group work and TEYL. According to Tamah (2017), Harmer (1998) and Gillies (2003) group work is the activity where students sit together with the other group member to discuss the same topic and to achieve the same goal. It had been in line with the data of the study that showed the understanding of the teachers toward the definition of group work. Regarding to TEYL, most teachers realized that teaching young learners was not that easy and needed more preparation before applying it. The proper materials became one of the teachers' concerns to keep young 
learners' attention during the teaching-learning process. Those understandings were same as what Brown (2001) stated that children had short attention and was easily distracted by something else. He suggested teachers to ensure the material become more animated, lively, and enthusiastic so children would be more curious toward the material being taught.

Second, the implementation of group work was the picture of whether the group work would be applied successfully or not. Brown (2001) stated that the variety of group work activity would play a role in the effectiveness of group work. Tamah (2017) also implied that determining the number of the group, demonstrating the rules, and considering the name of the group were important in conducting group work. Based on the data collected, the researcher found out that most teachers agreed to the statements in the second category of the questionnaire. Although there was one teacher disagreed towards the statement "Teachers should consider the name of the group", the other was fine about that. The last category was responded positively by the teachers. They realized that student would learn how to communicate with others and respect to the others' ideas when children were being set into the group work situation. Group work did not only encourage them to be good academically, yet it also taught them how to behave well in their social environment. Sofroniou and Poutos (2016) stated that group work leads students to develop their communication skill, critical thinking, appreciation and respect other views, and reinforce in-depth understanding towards the learning materials. Those reasons became the teachers' consideration to include group work as one of the teaching methods in their teaching-learning process.Building upon the finding above, it could be seen that they experienced toward group work. The three categories of the questionnaire were also in line what they thoughts about group work. So, it could be concluded that teachers gave positive perception toward the statements in the questionnaire. 
The second data of this research was from the interview. It was used to support enrich the data from the questionnaire. In the interview, the researcher found out that most teachers argued that group work was important to be applied in teaching English to young learners. Social interaction was frequently mentioned by them to support group work in the teaching-learning process. It was because young learner would have a discussion during group work activity which involved students to share and respond to the other group member ideas. Another opinion that frequently appeared was the group work supported student center learning and helped the teachers to avoid student boredom. It was in line to what Cameron said in 2001 about characteristic of children. She stated thatyoung learners could lose their interest easier than adult learners could. Based on the teachers' confession, the main cause of student's boredom was because they were not interested in doing the same thing over and over again such as listening to the explanation. In contrast, group work provided them with different activities where students could talk about the same topic, share the ideas, and learn from the other group member. This made teachers consider group work as a good option for teaching English to Young Learners.

Even though group work displayed many benefits for many teachers, it still created a small problem. The researcher found out that teachers encountered the barriers in implementing group work to young learners. That main barrier was student focus, many teachers stated that students preferred talking about something which was out of the material instead of discussed the assignments given by the teachers. Some teachers also added that students tended to play rather than finished their work during group work activity. Nonetheless, the teachers were still able to handle those kinds of situations. They realized that it was a natural behavior of children. They suggested all teachers who would conduct group work, they should ensure the student understood to their job and kept monitoring the student while they were in a group setting. Last but not least, although there was still a barrier in implementing group work, most participants still 
recommended group work for teaching English to young learner. They said that group work could be used to enrich the variety of teaching method so that students would not get bored easily.

\section{Conclusion and Suggestion}

As stated in the formulation of the problem in the previous chapter, this study aims at finding teachers' perception towards the implementation of group work in teaching English to young learners. According to the findings and discussion in the previous chapter, several terms can be concluded. First, the teachers have good basic knowledge about group work and teaching English to young learners. Second, they also come with the positive response toward the implementation of group work because they have experienced on it. The last, a number of teachers recommend that group work is one of the funs teaching strategies that teacher should carry out in their teaching-learning process. Overall, teachers havea positive perception towards the implementation of group work in teaching English to young learners.

In line with the conclusion, the researcher suggests the teachers to monitor the students when they are dealing with group work activities and preparing the group work activities properly before conducting the group work. While for the future researchers, the researcher suggests to examine group work in terms of assessment, investigate group work in teaching adult learners and invite more participants to involve in the study.

\section{References}

Ahmed, I. (2013). Importance of Group Work for ESL Students in Bangladesh: A Tertiary Level Perspective.

Arifin, R. (2014). Pesepsi Guru Terhadap Implementasi Kurikulum 2013 Bidang Keahlian Tehnik Bangunan di SMK Negeri 2 Yogyakarta. 
Arikunto, S. (1995). Prosedur Penelitian Suatu Pendekatan Praktik. Jakarta: Rineka Cipta.

Ary, D., Jacobs, L. C., Sorensen, C., \& Razavieh, A. (2010). Introduction to Research in Education (8 ed.). USA: Wadsworth.

Blatchford, P., Kutnick, P., Galton, M., \& Baines, E. (2002). Improving the Effectiveness of Pupils Groups in Classrooms. ESRC/TLRP.

Brown, H. D. (2001). Teaching by Principles: An Interactive Approach to Language Pedagogy. New York: Longman.

Cameron, L. (2001). Teaching English to Young Learners. UK: Cambridge University Press.

Gillies, R. M. (2003). The Behaviors, Interactions, and Perceptions of Junior High School Students During Small-Group Learning. Journal of Education Psychology, 137-147.

Harmer, J. (1998). How to Teach English. England: Longman.

Heigham, J., \& Croker, R. A. (2009). Qualitative Research in Applied Linguistics. New York: Palgrave Macmillan.

Mathers, N., Fox, N., \& Hunn, A. (2007). Surveys and Questionnaires.

Raja, N. (2012). The Effectiveness of Group Work and Pair Work for Students of English at Undergraduate Level in Public and Private Sector Colleges. Interdisciplinary Journal of Contemporary Research in Business, 155-163.

Scott, W. A., \& Ytreberg, L. H. (1990). Teaching English to Children. New York: Longman.

Sofroniou, A., \& Poutos, K. (2016). Investigating the Effectiveness of Group Work in Mathematics. Education Sciences, 1-15.

Sugino, T. (1994). Small Group Work and Second Language Learning Among Japanese Learners of English. 102-121. 
Sugiyono. (2008). MetodePenelitian Kuantitatif, Kualitatif dan $R \& D$. Bandung: Alfabeta.

Tamah, S. M. (2017). Pernak-Pernik Kerja Kelompok Berbasis Pembelajaran Kooperatif. Surabaya: Universitas Katolik Widya Mandala Surabaya. 